\title{
Chemical Characterization on the Aromatic Composition of Cedrus Atlantica from Morocco in Two Geographical Areas will Break
}

\author{
Ayoub Ainane ${ }^{1}$, Fatima Khammour ${ }^{1}$, Mohammed el Kouali ${ }^{1}$, Mohammed talbi ${ }^{1}$, Asmaa Salamat ${ }^{1}$, Abdelkebir Kenz ${ }^{1}$, \\ Nawal Merghoub ${ }^{2}$, El Hassan Abba ${ }^{3}$, Sanaa Cherroud ${ }^{3}$ and Tarik Ainane ${ }^{3}$ \\ ${ }^{1}$ Laboratory of Analytical Chemistry and Physical Chemistry of Materials, University of Hassan II, Morocco \\ ${ }^{2}$ Green Biotechnology Center, MASCIR, Morocco \\ ${ }^{3}$ Superior School of Technology, University of Moulay Ismail, Morocco
}

Received: 制 February 21, 2018; Published: 眥 February 27, 2018

*Corresponding author: Tarik Ainane, Superior School of Technology, Khenifra (EST-Khenifra), University of Moulay Ismail, PB 170, Khenifra, 54000 Morocco, Morocco, Email: ainane@gmail.com

\begin{abstract}
Essential oils have various properties in different fields of application. This work entitled on the chemical characterization of Cedrus Atlantica of Morocco in two geographical zones will break: Cedrus Atlantica of Ajdir (khenifra region) (CAA) and Cedrus Atlantica of Wiwane (Azrou region) (CAW) which belongs to the family Pinaceae. The essential oils were extracted by hydrodistillation of the aerial parts (stems, leaves and flowers) of Atlantica Cedrus and analyzed by gas chromatography-mass spectrometry (GC-MS). The analyzes show that Cedrus Atlantica Ajdir (CAA) has $\beta$-Himachalene as the major constituent of this essential oil with a content of approximately $(31,24) \%$, followed by $\alpha$-Himachalene $(15,63 \%)$ and $\gamma$-Himachalene $(14.46 \%)$, with a percentage of $61.33 \%$. For Wiwane Cedrus Atlantica (CAW) $\beta$-Himachalene (28.85\%), $\alpha$-Himachalene (17.93\%) and $\gamma$-Himachalene (16.52\%) are the major constituent, with a percentage of $63.3 \%$.The recorded yields are: 1.94\%) for Cedrus Atlantica of Ajdir (CAA) and (2.09\%) for Cedrus Atlantica of Wiwane (CAW).
\end{abstract}

Keywords: Essential oil; Cedrus Atlantica; GC-MS; Aromatic compositions

\section{Introduction}

For centuries, humans have used plants in several fields, such as perfumery, pharmacology and food, thanks to their properties discovered by chance [1]. The genus Cedrus is an ancient genus known from the Tertiary with a broad distribution, it includes four species: Atlas cedar, Lebanon cedar, Himalayan cedar and Cyprus cedar [2]. The area occupied by natural cedar is divided into three large areas, Lebanon (160000 ha), Himalaya (500000 ha) and Morocco and Algeria [3]. Morocco has a natural variety of very diverse aromatic plants [4]. These aromatic plants are at the origin of products with very high added value which can contribute to the economic development of the country, and which could constitute an important capital for its sustainable development [5]. These many aromatic species that can provide essential oils, are used in various fields for their therapeutic and organoleptic properties, including fragrant (perfumery, cosmetic) [2,6].

\section{Materials and Methods}

\section{Collection of samples}

Samples of the aerial part (stems, leaves and flowers) Cedar of Ajdir (Khenifra-Morocco) and Cedar of Wiwane (Azrou-Morocco) were harvested in September (2017) both species were verified by a botanists at EST-Khenifra, Morocco (Professors E. Abba and S. Cherroud).

\section{Extraction of essential oils from cedrus}

The essential oils were obtained by hydrodistillation of the aerial parts (stems, leaves and flowers) in fractions of $250 \mathrm{~g}$ for a period of $3 \mathrm{~h}$, using a Clevenger type extractor. Water vapor laden with essential oils condenses in a coolant and is collected in a separatory funnel and dried with anhydrous sodium sulphate 
(Na2SO4) before analysis [7]. HEs were stored at $4^{\circ} \mathrm{C}$ for later use in the various assays [8].

\section{Gas chromatography (GC)/mass spectrometry (MS)}

The analysis of the essential oils was carried out by gas chromatography coupled with mass spectrometry (GC-MS). Coupling was performed on a Hewlett-Packard model 5970 (quadrupole detection system), equipped with a fused silica

\section{Results and Discussion}

\section{Chemical compositions}

Table 1: Chemical compositions of essential oils of Cedrus Atlantica from Ajdir (CAA) and from Wiwane (CAW).

\begin{tabular}{|c|c|c|}
\hline Identification & Cedrus Atlantica (CAA) & Cedrus Atlantica (CAW) \\
\hline Limona ketone & 0.55 & 0.84 \\
\hline (-)-camphor & 0.02 & - \\
\hline$\alpha$-Bisabolol & 0.04 & 0.05 \\
\hline$\beta$-sinensal & 0.04 & 0.01 \\
\hline endo-Borneol & 0.02 & - \\
\hline p-Methylacetophenone & 0.1 & 0.05 \\
\hline$\alpha$-Terpineol & 0.05 & 0.1 \\
\hline 2,3,6-Trimethylphenol & 0.02 & 0.01 \\
\hline Dec-5-ene-3,7-diyne, 2,9-dimethyl- & 0.01 & 0.01 \\
\hline Tridecane & 0.02 & - \\
\hline$\alpha$-Longipinene & 0.16 & - \\
\hline$\gamma$-Amorphene & 0.02 & 0.13 \\
\hline$\beta$-Maaliene & 0.04 & 0.01 \\
\hline Ylangene & 0.09 & - \\
\hline$\alpha$-Copaene & 0.08 & 0.01 \\
\hline 1,3-Dimethylindane & 0.31 & 0.25 \\
\hline Aromandendrene & 1.55 & 1.02 \\
\hline Isoledene & 1.19 & 0.74 \\
\hline$\beta$-Santalol & 0.1 & - \\
\hline Himachala-2,4-diene & 0.79 & 1.02 \\
\hline$\alpha$-Himachalene & 15.63 & 17.93 \\
\hline ar-Himachalene & 0.51 & - \\
\hline$\gamma$-Himachalene & 14.46 & 16.52 \\
\hline$\beta$-Himachalene & 31.24 & 28.85 \\
\hline$\alpha$-Dehydro-ar-himachalene & 2.06 & 1.67 \\
\hline$\gamma$-Dehydro-ar-himachalene & 3.67 & 2.49 \\
\hline$\delta$-Cadinene & 1.93 & 1.1 \\
\hline trans-Calamene & 0.99 & 0.93 \\
\hline$\alpha$-Calacorene & 1.25 & 2.11 \\
\hline Pyrazole, 5-methyl-3-(5-nitro-2-furyl)- & 0.11 & - \\
\hline$\alpha$-Bisabolene & 1.08 & 2.02 \\
\hline himachalene oxide & 1.24 & 0.84 \\
\hline Longiborneol & 0.75 & 0.77 \\
\hline$(+)$ - $\beta$-Himachalene oxide & 2.3 & 3.96 \\
\hline$\beta$-Acoradiene & 0.58 & 0.71 \\
\hline
\end{tabular}

capillary column of $(2 \mathrm{~mm} \times 0.23 \mathrm{~mm})$ DB1 type; temperature programming from $50^{\circ} \mathrm{C}$ to $200{ }^{\circ} \mathrm{C}$ with a gradient of $5^{\circ} \mathrm{C}$ min- 1 . The retention indices were determined by gas chromatography on two fused silica capillary columns $(25 \mathrm{~m} \times 0.25 \mathrm{~mm})$ of the type OV101 and Cabowax 20M, with temperature programming identical to that used for the coupling. (Shimatzu GC-14A equipped with a flame ionization detector and a C-R4A model integrator). 


\begin{tabular}{|c|c|c|}
\hline Di-epi-1,10-cubenol & 1.44 & 2.7 \\
\hline$\delta$-Cadinol & 1.09 & 1.03 \\
\hline allo-Himachalol & 1.62 & 0.01 \\
\hline Cadalene & 0.38 & 0.05 \\
\hline 2,4-Diisopropylphenol & 0.7 & 1.99 \\
\hline Deodarone & 2.75 & 0.65 \\
\hline (Z)- $\gamma$-Atlantone & 0.85 & 0.09 \\
\hline (-)-Aristolene & 0.12 & 1.11 \\
\hline (E) $-\gamma$-Atlantone & 1.2 & 0.89 \\
\hline (Z)- $\alpha$-Atlantone & 1.24 & 0.16 \\
\hline Dehydroaromadendrene & 0.11 & 0.09 \\
\hline (-)-Eudesma-1,4(15),11-triene & 0.16 & 0.03 \\
\hline$\beta$-Atlantol & 0.13 & - \\
\hline one & 0.1 & 6.21 \\
\hline (E)-Atlantone & 4.3 & 0.06 \\
\hline Vestitenone & 0.36 & 0.05 \\
\hline 1,3,5-Trimethylpyrazole & 0.03 & - \\
\hline (E)- $\gamma$-Atlantone & 0.07 & 99.98 \\
\hline Total & 99.65 & \\
\hline
\end{tabular}

The gas chromatographic analysis results coupled with the mass spectrometry of the essential oils of the plants studied are shown in (Tables 1). Chromatographic analyzes of essential oils identified 53 compounds that represent approximately (99.65\%) for Cedrus Atlantica (CAA) and for Cedrus Atlantica (CAW) 43 compounds which represent approximately (99.98\%). The analysis of the results given in Table 1 showed the following results: for Cedrus Atlantica d'Ajdir (CAA) $\beta$-Himachalene is the major constituent of this essential oil with a content of approximately $31.24 \%$, followed by $\alpha$-Himachalene $15.63 \%$ and $\gamma$-Himachalene $14.46 \%$. The other constituents are detected as an average percentage: (E) -Atlantone 4, 30\%; $\gamma$-Dehydro-ar-himachalene 3.67\%; Deodarone 2.75\%; (+) - $\beta$-Himachalene oxide 2.30\%; $\alpha$-Dehydro-ar-himachalene $2.06 \%$; allo-Himachalol 1.66\%; Aromandendrene 1.55\%. For Wiwane's Cedrus Atlantica (CAW) $\beta$-Himachalene (28.85\%), $\alpha$-Himachalene $(17.93 \%)$ and $\gamma$-Hemachalene $(16.52 \%)$ are the major constituent of this essential oil, the other constituents are detected as an average percentage: (E) -Atlantone (6.21\%), $(+)-\beta$-Himachalene oxide $(3.96 \%), \gamma$-Dehydro-ar-himachalene $(2.49 \%), \alpha$-Calacorene $(2.11 \%)$. The content of the rest of the constituents is often less than $1 \%$ is considered minor constituents.

The results of (SARTANI, B, 2005) [9], indicate that E-aatlantone $28.75 \%$ and $\beta$-Himachalene $14.62 \%$ are the major constituents of the essential oil of Cedrus Atlantica sawdust. ; in this study (DERWICH, E, 2009) [10], reported that E-a-atlantone is absent in the essential oil of the leaves of this plant; which has as major constituents $\alpha$-pinene (14.85\%), followed by himachalene (10.14\%), $\beta$-himachalene $(9.89 \%)$ and $\sigma$-himachalene (7.62\%). Other studies show that Wiwane's Cedrus Atlantica (CAW) is rich

in terpenols $(26.40 \%)$ and ketones $(32.74 \%)$ and has the highest activity against germs [11].

It can therefore be concluded that the chemical composition or the percentage of the constituents of the essential oils differs according to the part of the plant subjected to the extraction. Other studies [12] have also shown that the chemical composition of the essential oils of Cedrus atlantica varies considerably according to the geographical zones the period of harvest and the age of the plant.

\section{Conclusion}

In the present work, we have characterized the chemical composition of Cedrus Atlantica essential oil from Morocco in two geographic areas will defer, Cedrus Atlantica of Ajdir (Khenifra) and Cedrus Atlantica of Wiwane (Azrou region). The identification of the chemical constituents was carried out on the basis of a GC-MS analysis. It can therefore be concluded that the chemical composition or percentage of the constituents of the essential oils differs according to the part of the plant subjected to the extraction, according to the geographical areas the harvest period and the age of the plant.

\section{References}

1. Bereksi Reguig, Yasmina Lemya (2016) Interactions entre l'huile essentielle de Thymus capitatus, Mentha piperita et Carthamus caeruleus de leur composants majoritaires: Effet du synergisme ou d antagonisme sur 1 activite antioxydante (Doctoral dissertation 04/01/2017).

2. El Haib, Abderrahim (2011) Valorisation de terpènes naturels issus de plantes marocaines par transformations catalytiques (Doctoral dissertation, Universite de Toulouse, Universite Toulouse III-Paul Sabatier). 
3. Boukerker, Hassène (2016) Auto-écologie et evaluation de la biodiversite dans les Cédraies de Cedrus atlantica Manetti dans le parc national de Belezma (Batna Algérie) (Doctoral dissertation Universite Mohamed Khider-Biskra).

4. Tarik Ainane (2011) Valorisation de la biomasse algale du Maroc: Potentialités pharmacologiques et applications environnementales cas des algues brunes Cystoseira tamariscifolia et Bifurcaria bifurcata (Doctoral dissertation Faculte des Sciences Ben M sik Universite Hassan II Casablanca).

5. Philippe Jouve (2012) Les oasis du Maghreb des agro-écosystèmes de plus en plus menacés Comment renforcer leur durabilite? Le Courrier de l'environnement de IINRA 62(62) 113-122.

6. Sarter, Samira, Danthu, Pascal, Randrianarivelo, et al. (2010) Etude de l'activite antimicrobienne d'une plante endémique de Madagascar Cinnamosma fragrans alternative aux antibiotiques en crevetticulture.

7. Laghchimi A, Znini M, Majidi L, Renucci F, El Harrak A, et al. (2014) Composition chimique eteffet des phases liquide et vapeur de l'huile essentielle de Lavandula multifida sur la croissance mycélienne des moisissures responsables de la pourriture de la pomme (Chemical composition and effect of liquid and vapor phaseof Lavandula multifida essential oil onmycelial growth of fungi responsible for the rot of apple) 5 (6) : 1770-1780.

8. Koba K, Sanda K, Raynauk C, Nenonene Y, Millet J, et al. (2004) Activités antimicrobiennes d'huiles essentielles de trois Cymbopogon sp. africains vis-àvis de germes pathogènes d'animaux de compagnie. Ann Med Vet 148: 202-206.

9. Sartani B (2005) Composition chimique et activite antimicrobienne des huiles essentielles extraites par hydrodistillation fractionnee du bois de Cedrus atlantica Manetti Laboratoire de chimie analytique et structurale associe au CNRSTP, UFR sciences et procedes d'analyses. Faculte des Sciences Ben M’Sik BP 7955 Casablanca, Maroc.

10. DERWICH E (2010) Chemical Composition and In Vitro Antibacterial Activity of the Essential Oil of Cedrus atlantica Unity of GC/MS \& GC Régional Center of Interface, University Sidi 12(3): 381-385.

11. Aberchane M, Ismaili My R, EL Abid A, Aafi A, Ghanmi M, et al. (2011) Diversite et valorisation des principales plantes aromatiques et médicinales (PAM) de l'écosystème cédraie au Maroc. Centre de Recherche Forestière 16.

\section{(a) (1) \\ This work is licensed under Creative Commons Attribution 4.0 License}

To Submit Your Article Click Here: Submit Article

DOI: 10.32474/AOICS.2018.02.000126

\section{AOICS}

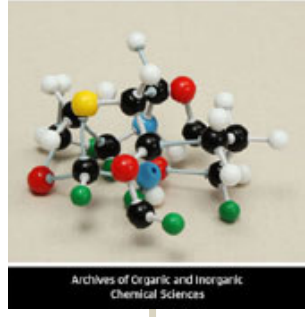

Archives of Organic and Inorganic Chemical Sciences

\section{Assets of Publishing with us}

- Global archiving of articles

- Immediate, unrestricted online access

- Rigorous Peer Review Process

- Authors Retain Copyrights

- Unique DOI for all articles 